\title{
Novel monoclonal antibodies against pathogenic Leptospira
}

\author{
Bruno Moisés de Matos*, Cláudia Pinho Hartleben, Leonardo Garcia Monte, Thais Farias Collares, \\ Biancia Sica Siedler, Francine Alves Sinnott \\ From 5th Congress of the Brazilian Biotechnology Society (SBBIOTEC) \\ Florianópolis, Brazil. 10-14 November 2013
}

\section{Background}

Leptospirosis is a zoonotic disease caused by pathogenic bacteria belonging to the genus Leptospira and more than 1 million cases occur worldwide annually. Several mammals may carry the agent, and rats are the most important source of human infection in urban settings. The Leptospira surface proteins have an important role during pathogen infection and some of these allow the differentiation between pathogenic and non-pathogenic species. Among these, the LigA and LigB adhesins are surface localized proteins that interact with the proteins of extracellular matrix and fibrinogen. Therefore, antibodies against these targets are useful tools in immunodiagnostic assays.

\section{Methods}

The goal of this study was to generated monoclonal antibodies (mAbs) against a truncated fragment of approximately $54 \mathrm{kDa}$, named rLigBrep, that comprise a identical portion of LigA and LigB (domains 2-7). For the mAbs production, two $\mathrm{BALB} / \mathrm{c}$ mice were inoculated via intraperitoneal with $150 \mu \mathrm{g}$ of rLigBrep on days $0,14,21$ and 28. Freund's complete adjuvant was used in the first dose and incomplete in the subsequent ones. Four days before cellular fusion the mouse with the highest titer in indirect ELISA (1:64000) was boosted with $20 \mu \mathrm{g}$ of protein intravenously. Splenic lymphocytes were fused to murine $\mathrm{Sp} 2 /$ O-Ag14 myeloma cells in the presence of PEG 1450. Fused cells were cultivated in Dulbecco's modified Eagle medium containing $20 \%$ fetal calf serum and supplemented with hypoxanthine, aminopterin and thymidine (HAT). Hybridomas growing in HAT medium were screened by indirect ELISA and those positive for rLigBrep were cloned twice by limiting dilution, expanded and stored in liquid nitrogen.

\section{Results and conclusion}

Two hibridomas (ID-Ra and ID-Rg) were obtained and used for ascites production. An indirect ELISA was performed to verify antibodies presence in ascites fluid. The mAbs presented high titres against rLigBrep (ID-Ra 51,200 and ID-Rg 128,000, respectively). In conclusion, the mAbs produced in this study can be useful tools in immunodiagnostic assays for leptospirosis.

\section{Acknowledgements}

We are grateful to Universidade Federal de Pelotas, Coordenação de Aperfeiçoamento de Pessoal de Nível Superior (Capes) and Cnpq (Conselho Nacional de Desenvolvimento Científico e Tecnológico).

Published: 1 October 2014

\section{References}

1. Adler B, de la Peña Moctezuma A: Leptospira and leptospirosis. Veterinary Microbiology 2010, 140(3-4):287-296

2. Harlow E, Lane D: Antibodies: A Laboratory Manual Cold Spring Harbor Laboratory Press. NY: Cold Spring Harbor; 1988.

3. Monte LG, Conceicao FR, Coutinho ML, Seixas FK, da Silva EF, Vasconcellos FA, deCastro LA, Hartleben CP, Dellagostin OA, Aleixo JA: Monoclonal antibodies against the leptospiral immunoglobulin-like proteins $\mathrm{A}$ and $\mathrm{B}$ conserved regions. Comparative Immunology. Microbiology \& Infectious Diseases 2011, 34(5):441-446.

\section{doi:10.1186/1753-6561-8-S4-P59}

Cite this article as: de Matos et al:: Novel monoclonal antibodies against pathogenic Leptospira. BMC Proceedings 2014 8(Suppl 4):P59. 